\section{Metafora Anggota Tubuh dalam Masyarakat Muna}

\author{
Andi Wardatul Wahidah Lufini \\ Linguistics Master Program, \\ Universitas Gadjah Mada \\ wardatulwahidah96@mail.ugm.ac.id
}

\begin{abstract}
ABSTRAK
Makalalah bertujuan untuk menjelasakan konseptualisasi anggota tubuh dalam ungkapan-ungkapan metaforis di masyarakat Muna. Muna merupakan salah satu nama suku sekaligus bahasa yang merupakan rumpun bahasa Austronesia dengan sub-grub Muna-Buton. Dalam berkomunikas masyarakat pengguna bahasa ini juga tidak lepas dari adanya pemetaforaan. Terdapat empat topik metafora yang paling sering dijumpai dalam yaitu yang berkaitan dengan hewan, tumbuhan, istilah kekeluargaan dan anggota tubuh. Diantara istilah-istilah yang berkaitan dengan metafora tersebut, anggota tubuh merupakan pemetaforaan yang paling banyak digunanakan oleh masyarakat Muna dibandingkan dengan metafora dengan istilah kekeluargaan, hewan dan tumbuhan. Cara pandang yang berbeda menyebabkan kekhususan konsep dan dasar pemetaforaan bagi setiap kelompok masyarakat. Data dalam penelitian ini merupakan ungkapan-ungkapan metaforis yang diambil melalui kamus online bahasa Muna yang dapat diakses melalui laman https://www.webonary.org/muna/?lang=en. Pembicaraan dilakukan dengan menggunakan pendekatan semantik kognitif sedangkan analisis data akan dilakukan dengan menggunakan teori Great Chain Methapor Theory (GCMT). Hasil dari penelitian ini mengungkapkan bahwa dipilihnya anggota tubuh sebagai bagian dari istilah-istilah dalam metafora terjadi bukan tanpa alasan. Setidaknya terdapat empat hal yang mendasari penggunaan anggota tubuh dalam istilah bermetafor. Keempat hal tersebut adalah letak, fungsi, sifat dan bentuk dari anggota tubuh tersebut. Selain membuktikan bahwa terbatasnya kosa kata tidak membuat kreatifitas pengguna bahasa menjadi sempit hal ini juga membuktikan bahwa masyarakat menggunkan sesuatu yang sangat dengan dengan lingkungan sosial dan budaya dalam mengkonstruksi sebuah metafora.
\end{abstract}

Kata Kunci: anggota tubuh; metafora; bahasa muna

\title{
PENDAHULUAN
}

Mayoritas pembahasan mengenai fungsi metafora dikaji sebagai unsur penambah keindahan dalam puisi, novel dan karya sastra lainnya. Namun selain dari pada itu, memahami alasan dibalik pemetaforaan juga dapat mengungkapkan fungsi lain metafora sebagai visualisasi cara pandang masyarakat penggunanya. Merujuk pada penjelasan mengenai metafora menurut Kridalaksana yang didefiniskan sebagai pemakaian kata atau ungkapan untuk suatu objek lain berdasarkan kias atau persamaan (dalam Haula 2020), maka potensi penggunaan elemen yang sangat familiar dengan manusia dalam ungkapan bermetafor sangat besar adanya. Tradisi dan budaya yang berbeda mempengaruhi pengertian dan sudut pandang setiap kelompok masyarakat dalam memaknai sebuah benda atau peristiwa, sehingga akan berbeda pula dalam menggukan variasi-variasi kebahasaan tersebut.

Blust (2013) dalam bukunya menuliskan bahwa bahasa-bahasa Austronesia sangat kaya akan ungkapan-ungkapan bermetafora. Beberapa diantaranya menjadi topik metafora yang paling sering muncul keempat topik tersebut berhubungan dengan: 1) anggota tubuh, 2) istilah-istilah kekeluargaan, 3) tumbuhan, dan 4) hewan. Sebagai salah satu bagian dari bahasa Austronesia bersubgrub Muna-Buton, keempat topik ungkapan tersebut juga dapat kita temukan dalam bahasa Muna. Salah satu ungkapan metafora yang berkaitan dengan hewan dapat kita jumpai dalam kata foadhara yang merupakan gabungan antara morfem fo- yang memiliki makna "membuat jadi" dan kata benda adhara yang berarti "kuda". Ungkapan ini tercipta dari hasil konseptualisasi masyarakat dengan membandingkan hewan kuda dengan manusia (budak). Secara historis pada abad ke 16, Lakina Titakono membagi masyarakatnya menjadi tiga golongan umum yaitu golongan Kaomu, [25 - 33] 
Walaka, dan Maradika. Golongan Maradika yang melakukan kejahatan kemudian dihukum menjadi budak (Couvreur 2001). Para budak dapat dikatakan tidak memiliki hak atas dirinya sendiri sehingga mereka dapat dipaksa untuk melakukan apa saja, terutama pekerjaan berat. Masyarakat Muna mengkonseptualisasi peristiwa ini dengan membandingkan dua nomina yaitu "budak" dan hewan "kuda" berdasarkan persamaan fungsi dari kedua benda tersebut. Kuda dalam masyarakat Muna hanya dimiliki oleh kaum bangsawan, selain itu kuda juga difungsikan untuk melakukan pekerjaan berat misalnya sebagai alat angkut. Atas dasar inilah masyarakat menggunakan hewan "kuda" untuk menggambarkan kondisi seorang budak.

Dalam jumlah yang lebih terbatas, istilah yang menggunakan tumbuhan dan istilah kekeluargaan juga dapat ditemui di masyarakat Muna misalnya dalam ungkapan pughuno liwu. Dimana sifat dari batang pohon (pughu) yang tegak lurus menjadi dasar pemetaforaan. Untuk istilah yang menggunakan ungkapan kekeluargaan, terdapat dua istilah yang paling sering digunakan yaitu istilah ina yang berarti induk dan ana yang berarti anak. Jika dibandingkan dengan bahasa Indonesia, terdapat beberapa istilah yang berbeda dalam penggunaannya. Misalnya dalam bahasa Indonesia, terdapat istilah busur dan anak panah, sementara dalam bahasa Muna istilah kekeluargaan justru terdapat pada kata inano pana yang berarti "induk panah" dan pana yang berarti anak panah. Hal ini menunjukkan terjadi perbedaan pola pikir dan cara pandang dari kedua masyarakat penutur bahasa tersebut.

Beberapa bukti diatas menunjukkan bahwa pemetaforaan terjadi bukan tanpa alasan. Menurut Kovesces (dalam Nirmala 2012) terdapat tiga komponen yang menjadi dasar suatu masyarakat dalam mengonseptualisasikan sesuatu yang dirasakan atau sesuatu yang lebih abstrak dengan menggunakan sesuatu yang lebih konkret yaitu pertama, ranah sumber (source domain), ranah target (target domain) dan dasar metafora. Cara pandang atau budaya suatu masyarakat terhadap sebuah peristiwa akan sangat berpengaruh terhadap metafora yang akan mereka gunakan. Hal yang sama juga dijelasakan dalam Wijana (2020) bahwa manusia akan sangat dipengaruhi oleh budaya disekitar mereka dalam mencari source domain dari metafora yang akan mereka bentuk.

Salah satu topik metafora yang dapat dijumpai pada bahasa-bahasa Austronesia adalah metafora anggota tubuh sebagai salah satu usur yang paling dekat dengan manusia. Hal ini dapat terlihat dari beberapa penelitian sebelumnya yang berhubungan dengan anggota tubuh misalnya penelitian dari Subhan, dkk (2019). Dari penelitian ini dapat diketahui bahwa "tangan" memiliki beberapa konseptualisasi sifat dan perbuatan dalam Al-Qur'an diantaranya sifat kikir, sifat pengasih, sifat benci, dan sifat berlebihan. Sedangkan perbuatan yang di metaforkan menggunakan kata "tangan" misalnya pemalsuan, maksiat, menyerang, menyentuh dan pertanggung jawaban. Pemetaforaan anggota tubuh yaitu "tangan" juga pernah diteliti penggunaannya dalam idiom bahasa Jepang oleh Rachmawati (2019) dengan hasil bahwa konsep "tangan" dalam idiom bahasa Jepang merupakan pemetaforaan dari aktivitas/pekerjaan, kepemilikan, hubungan, sikap, siasat, kemampuan/keterampilan, bantuan, keahlian/kepandaian.

Sementara itu bagaimana anggota tubuh yang digunakan sebagai piranti lingual dalam metafora orientasional juga telah diteliti oleh Lyra (2016) dari penelitian ini diketahui bahwa anggota tubuh diungkapkan melalui peranti lingual bahasa Sunda dalam bentuk monomorfemis (kata dasar) dan polimorfemis (kata jadian, frasa, kata majemuk, idiom dan klausa). Melalui penelitian-penelitian tersebut dapat diketahui bagaimana masyarakat Arab, Jepang, dan Sunda merepresentasikan sebuah peristiwa menggunakan metafora anggota tubuh. Penelitian kebahasaan mengenai konsep metafora secara umum dalam pantun kabhanti Muna telah diteliti oleh Apriatin (2015) melalui penelitian ini diketahui bagaimana sikap dan budaya masyarakat Muna dalam beberapa hal misalnya mendidik anak. Tulisan ini akan secara khusus membicarakan tentang metafora-metafora yang menggunakan anggota tubuh dalam bahasa Muna sebagai salah satu bahasa Austronesia dengan tujuan untuk menjelaskan bagaimana cara pandang masyarakat Muna dalam mengkonseptualisasi suatu peristiwa sehingga menggaitkan penamaan peristiwa atau benda dengan salah satu anggota tubuh.

Penelitian ini menggunakan pendekatan semantik kognitif. Pendekatan ini merupakan landasan untuk mengungkapkan proses mental untuk menginterpretasi metafora yang menggunakan anggota tubuh dari ranah suber ke ranah target menggunakan teori Great Chain Methaphor Theory 
(GCMT). Menurut Konvesces dalam Chaerani (2017) teori ini menjabarkan bagaimana objek atau benda di dunia ini dikonsepsikan secara metafor. Data dalam penelitian ini berupa metaforametafora dalam bahasa Muna yang menggunakan anggota tubuh sebagai salah satu unsur pembentuknya (Yusuf 2016). Data-data ini diperoleh dengan menggunakan teknik dokumentasi dengan mengumpulkan data-data terkait melalui kamus daring bahasa Muna melalui laman https://www.webonary.org/muna/?lang=en yang telah diterbitkan oleh SIL pada tahun 2013. Hal ini sesuai dengan definisi dari metode dokumentasi sendiri dimana metode ini bertujuan menelusuri data historis dengan mencatat data-data yang sudah ada. Langkah selanjutnya setelah mengumpulkan data adalah data dianalisis menggunakan teori GCMT dengan mempertimbangkan konteks budaya dari masyarakat Muna. Untuk memastikan apakah pemaknaan terhadap data-data tersebut tepat, hasil penafsiran ini kemudian dikonfirmasikan melalui wawancara telepon dengan beberapa penutur asli bahasa Muna sehingga juga akan diperoleh tambahan informasi mengenai data yang telah dianalisis.

\section{HASIL DAN PEMBAHASAN}

Berdasarkan data-data yang telah dikumpulkan terdapat setidaknya 12 anggota tubuh yang digunakan masyarakat Muna dalam membentuk metafora. Kedua belas anggota tubuh tersebut yaitu:

\section{Fotu (Kepala)}

Metafora yang menggunakan kata fotu dapat ditemui dalam ungkapan-ungkapan berikut:

\begin{tabular}{|c|c|c|}
\hline Fotuno bhara & & Bhara $(n)=$ angin barat \\
\hline Fotuno mawa & & Mawa $(n)=$ arus/banjir \\
\hline Fotuno kawea & $\begin{array}{l}\text { fotu(n) [kepala] + -no } \\
\text { [sufix. kepemilikan IIIt] }\end{array}$ & Kawea $(n)=$ angin \\
\hline Fotuno kafeena & & Kafeena $(n)=$ seserahan \\
\hline
\end{tabular}

Bagian tubuh "kepala" memiliki tiga bentuk makna yaitu utama, atas, dan permulaan. Makna kata permulaan akan digunakan pada peristiwa-peristiwa alam seperti banjir atau pergantian musim. Contohnya pada ungkapan fotuno bhara dan fotuno mawa. Makna kata atas akan digunakan pada benda-benda yang dianggap memiliki subbagian misalnya atas atau bawah, tinggi atau rendah. Contohnya pada ungkapan fotuno laa dan fotuno lani. Sementara makna kata utama akan diasosiasikan pada benda atau peristiwa yang memiliki tambahan kata "paling" melekat pada frasa. Misalnya pada ungkapan fotuno kawea (angin paling keras) dan fotuno kafeena (seserahan paling penting).

Berdasarkan data-data tersebut diketahui bahwa anggota tubuh kepala memiliki beberapa keutamaan dibandingkan anggota tubuh yang lain. Bentuk-bentuk makna tersebut selain didasari pada pandangan masyarakat Muna bahwa kepala merupakan bagian paling penting dari manusia sesuai dengan letaknya yang berada dibagian paling atas, digunakan untuk berakal pikiran dan merupakan bagian yang pertama kali terlihat ketika manusia dilahirkan. Beberapa larangan perlakuan terhadap anggota tubuh ini di masyarakat Muna juga membuktikan bahwa bagian tubuh ini dianggap sebagai bagian penting misalnya larangan agar tidak menyentuh kepala orang lain tanpa izin dan larangan untuk tidak memukul bagian kepala. Secara ringkas pemetaforaan anggota tubuh "kepala" dapat dipetakan sebagai berikut. 
Tabel.1 Peta metafora anggota tubuh fotu (kepala)

\section{Ranah Sumber}

Fotu

\section{Ranah Target}

\section{Fotuno bhara}

Makna Kultural : permulaan [musim barat]

situasi awal yang dirasakan dalam kurun waktu ketika arah angin mulai berubah dari timur ke barat

\author{
Fotuno mawa \\ Makna Kultural : permulaan arus \\ gelombang air pertama dan paling depan dari sebuah \\ arus. \\ Fotuno kawea \\ Makna Kultural : angin puting beliung \\ Jenis angin yang paling ditakuti karena merupakan jenis \\ angin tercepat yang pernah dirasakan penduduk
}

\section{Bagian tubuh paling awal yang terlihat ketika manusia dilahirkan, paling atas, dan paling penting.}

\section{Fotuno kafeena}

Makna Kultural : seserahan berupa cincin

bagian paling penting dari pernikahan, berisi cincin. Pembawa bingkisan ini berjalan paling depan dari barisan seserahan.

\section{Fotuno laa}

Makna Kultural : hulu sungai

Merupakan bagian sungai yang terletak paling atas, dataran tinggi atau pegunungan. biasa juga disebut sebagai pusat atau sumber air

\section{Fotuno lani}

Makna Kultural: bagian langit yang terlihat sangat jauh berada di atas kepala ketika mendongak

\section{Ghaghe (kaki)}

Pemetaforaan menggunakan anggota tubuh kaki dapat dijumpai pada ungkapan-ungkapan berikut:

a. Ghaghe mbari --- ghaghe (n) [kaki] + mbari (adj) [banyak]

b. Ghagheno lani --- ghaghe (n) [kaki], -no (suffix. Kepemilikan IIIt) + lani (n) [langit]

c. Ghaghe nsaho --- ghaghe (n) [kaki] + nsaho (n) [kasau]

d. Ghagheno tumpu --- ghaghe (n) [kaki], -no (suffix. Kepemilikan IIIt) + tumpu (n) [kayu]

Berdasarkan data-data tersebut kata kaki memiliki tiga bentuk makna berdasarkan dua perspektif yang berbeda yaitu berdasarkan fungsi dapat ditemukan dalam ungkapan bermakna penopang, dan berdasarkan perspektif letak, dapat ditemukan dalam makna rendah dan sisa. Ghahge mbari (kaki banyak) istilah yang digunakan untuk merujuk pada salah satu jenis akan yaitu akar tunjang. Dasar pemetaforaan ini adalah fungsi dari akar dan kaki manusia yang memiliki kesamaan yaitu untuk menopang anggota lainnya sehingga dapat berdiri dengan tegak dan terletak dibagian bawah. Sedangkan kata mbari yang berarti banyak ditambahkan pada istilah tersebut dikarenakan akar 
tunjang memiliki banyak cabang akar yang mencuat dari batang pohon. Kesamaan sifat dan bentuk inilah yang membuat masyarakat Muna menamakan akar tunjang dengan istilah ghaghe mbari.

Ungkapan lain yang berkaitan dengan istiah ghaghe adalah ghagheno lani yang bermakna "kaki langit". Penggunaan anggota tubuh "kaki" dimaksudkan karena anggota tubuh ini memiliki letak yang paling rendah dari anggota tubuh lainnya. Sehingga ungkapan ini merujuk pada bagian langit yang terlihat sangat rendah dan berbatasan langsung dengan permukaan bumi. Makna yang sama juga dapat ditemukan dalam ungkapan ghaghe nsaho yang bermakna harfiah "kaki kasau" namun secara kultural istilan ini merujuk pada bagian dari para-para rumah yang sangat rendah dan hampir menyentuh atap rumah. Hubungan antara makna harifiah dan makna kultural dari istilah ini masih dapat dilacak karena ketika mendirikan atau rumah maka diperlukan kayu-kayu kasau yang dipasang melintang sehingga daerah bagian bawah kasau-kasau tersebut yang hampir menyentuh atap rumah distilahkan dengan ghaghe nsaho.

Makna kultural yang terakhir yaitu "sisa" dapat ditemukan dalam istilah ghagheno tumpu yang secara harfiah bermakna kaki kayu namun secara kulturan bermakna sisa-sisa pembakaran. Hal ini didasari pada pemahaman pada saat terjadi proses pembakaran, ujung kayu yang pertama kali tersentuh oleh api di sebut sebagai fotuno sau sehingga secara otomatis bagian paling bawah yang kadang bahkan tidak terbakar disebut sebagai ghagheno tumpu.

\section{3. mata (mata)}

Metafora yang menggunakan kata mata dapat dijumpai dalam ungkapan-ungkapan berikut.

a. Mata nsala --- mata (n) [mata] + nsala (n) [jalan]

b. Mata gholeo --- mata (n) [mata] + gholeo (n) [matahari]

c. Mata dadu --- mata (n) [mata] + dadu (n) [dadu]

d. Dai mata --- dai (adj) [rusak] + mata (n) [mata]

e. Angka nemata --- angka (v) [melalui] + ne- (prep) [di] + mata (n) [mata]

Anggota tubuh "mata" bagi masyarakat Muna diidentikkan dengan sesuatu yang menjadi penunjuk atau patokan. Pandangan yang mendasari hal ini adalah fungsnya untuk melihat sehingga apa yang terlihat oleh mata merupakan sesuatu yang akan dikonsepsikan oleh pikiran manusia, menjadi penunjuk tentang apa yang dilakukan, atau menjadi patokan untuk melakukan penilaian terhadap sesuatu. Secara ringkas pemetaforaan terhadap anggota tubuh mata dalam bahasa Muna dapat dipetakan sebagai berikut.

Tabel 2. Peta metafora anggota tubuh mata (mata)

\begin{tabular}{ll}
\hline Ranah Sumber & Ranah Target \\
\hline Mata & Mata nsala \\
& Makna Kultural : penunjuk jalan \\
& Masyarakat Muna akan menggunakan penunjuk jalan \\
ketika memasuki hutan dengan tujuan agar tidak tersesat & dan tidak diganggu oleh penunggu hutan \\
& Mata gholeo \\
& Makna Kultural : arah timur \\
& siang hari (waktu bekerja) lebih utama dibandingkan \\
& malam hari (waktu beristirahat). Matahari merupakan \\
& patokan dimulainya hari yang baru sehingga jika cahaya \\
mulai menyemburat dari ufuk timur maka saat itulah & pekerjaan harus dimulai. \\
Mata dadu & Makna Kultural : firasat/dugaan \\
Bagian tubuh yang menjadi & Dengan membaca tanda-tanda yang ada disekitarnya \\
kunci konsepsi pikiran manusia, & masyarakat Muna akan berusaha mendapatkan petunjuk \\
penunjuk, atau patokan. & melalui firasat tentang apa yang akan terjadi/dilakukan. \\
\hline
\end{tabular}


Makna Kultural: tidak senang

Segala perbuatan akan pertama kali terlihat oleh mata manusia yang kemudian akan menjadi patokan penilaian masyarakat. Sehingga, ungkapan dai mata bermakna merusak penilaian masyarakat.

\section{Angka mata}

Makna Kultural : sistem perkawinan resmi

Sistem perkawinan dimana sang lelaki datang meminang si gadis disaksikan oleh sanak keluarga dan handai tolan. Sistem ini merupakan patokan dari bagaimana suatu prosesi seharusnya dari suatu pernikahan.

\section{4. wubha (mulut)}

Metafora dengan anggota tubuh wubha dapat di jumpai dalam ungkapan-ungkapan berikut.
a. Wubhano laa
b. Wubhano ghahu
c. Wubhano randa
Wubha $(n)=$ mulut
$+$
-no (suflx kepemilikan IIIt)
ghagu $(n)=$ loteng
randa $(n)=$ perut atas
laa $(n)=$ sungai

Masih berkenaan dengan fungsi organ "mulut" yaitu sebagai tempat memasukkan makanan. Penggunaan metafora dengan menggunakan kata "mulut" juga mengadopsi unsur "memasukkan" sehingga kata wubha dalam contoh-contoh istilah diatas bermakna "jalan masuk" atau "pintu". Misalnya pada ungkapan wubhano laa yang berarti muara sungai. Diketahui muara sungai adalah wilayah badan air tempat masukknya satu atau lebih sungai ke laut, samudra, danau, bendungan, atau bahkan sungai lain yang lebih besar. Demikian pula pemaknaan kata wubha dalam istilah yang kedua dimana kata ini dimaknai sama seperti pintu. Masyarakat Muna memanfaatkan para-para rumah mereka untuk menyimpan hasil pertanian baik berupa jagung atau umbi-umbian. Untuk memasukkan hasil pertanian tersebut ke loteng rumah maka dibuatlah sebuah pintu yang diistilahkan dengan wubhano ghahu. Sedangkan pegistilahan epigstrium dengan kata wubhano randa dimaksudkan karena daerah ini merupakan pintu penghubung dari tulang kerongkongan yang sempit menuju ke bagian perut yang dianggap lebih lapang.

\section{5. bhaga (pipi)}

Pemetaforaan sesuatu menggunakan kata pipi dalam bahasa Muna lebih di dasari pada bentuk dari pipi itu sendiri yang terlihat menonjol. Metafora dengan menggunakan anggota tubuh pipi dapat ditemui dalam ungkapan-ungkapan bhagano ghohia yang berarti bongkahan besar garam atau pada ungkapan bhagano koro yang merujuk pada bagian yang terlihat menonjol pada bokong.

\section{6. pongke (telinga)}

Pemetaforaan dengan menggunakan istilah pongke memiliki dua dasar yaitu bentuk dan fungsi dari telinga. Pemetaforaan dengan dasar persamaan pada bentuk telinga dapat ditemui pada ungkapan pongkeno nuhua atau pongkeno tonde yang berarti gagang belanga atau gagang gelas. Sedangkan ungkapan yang menggunakan fungsi dari telinga sebagai dasar metafora dapat dijumpai dalam ungkapan rindima pongke dan tagho pongke. Ungkapan rindima (adj. dingin) + pongke digunkan untuk merujuk pada perkataan atau ucapan yang enak didengar. Istilah ini hampir memiliki kesamaan dengan ungkapan nomagolai pongke gabungan dari morfem no- (prefiks, melekat pada kata sifat yang menunjukkan adanya orang lain diluar frasa yang melakukan kata kerja) + ma- (infiks. keseluruhan) + gola (n. gula) + -i (konfiks yang menyatakan pekerjaan yang telah dilakukan). Sehingga secara harfiah morfem tersebut berarti "melumuri telinga dengan gula" namun secara kultural istilah tersebut merujuk pada perkataan yang dimanis-maniskan walaupun tidak sesuai dengan kenyataannya. Sedangkan istilah tagho pongke merujuk pada makna "menguping" dimana kata tagho berarti menadah. Dalam hal ini pembicaraan diibaratkan seperti air yang di tadah dalam wadah dan wadah yang dimaksud adalah organ telinga. 
Dalam jumlah yang lebih sedikit, terdapat anggota-anggota tubuh lain yang digunakan dalam pemetaforaan, misalnya:

1) Lela ghule (lidah ular). Ular merupakan binatang buas yang paling banyak di jumpai di daerah Muna. Jika dibandingkan dengan penggunaan istilah yang sama dalam bahasa Indonesia, istilah ini digunakan untuk merujuk pada orang yang tidak tetap kata-katanya dengan dasar pemetaforaan bentuk dari lidah ular yang memiliki dua cabang. Sedangkan dalam bahasa Muna dasar pemetaforaan terdapat pada pemahaman bahwa lidah merupakan salah satu alat ucap yang penting dan sifat lidah ular yang terus-terusan menjulur keluar. Sehingga istilah lela ghule ditujukan untuk seorang pembual yang terus-terusan berbicara terutama dengan maksud untuk menyombongkan diri.

2) Wughu ghule (leher ular), istilah ini digunakan untuk merujuk pada orang yang memakan segala jenis makanan dalam porsi besar. Kondisi geografis daerah Muna yang berbatu kapur dan memiliki banyak liang atau terowongan kecil memudahkan berbagai jenis hewan melata untuk bersembunyi sehingga jenis ular yang ditemukan lebih beragam. Tidak jarang di Muna di jumpai kasus dimana seekor ular tidak hanya menelan hewan yang lebih kecil dari tubuhnya bahkan binatang buas ini juga menelan sesuatu yang berukuran lebih besar seperti anak sapi bahkan manusia. Orang yang senantiasa melahap sesuatu dalam jumlah yang besar dianggap memiliki kerongkongan yang sama seperti ular dapat menelan sesuatu yang lebih besar.

3) Kalima-lima [ka- (prefiks yang menyatakan kebiasaan) lima-lima (perulangan dari kata lima yang menunjukkan sesuatu terjadi berkali-kali] dasar pemetaforaan dari anggota tubuh lima yang berarti tangan adalah fungsi dari tangan itu sendiri yang digunakan untuk "mengambil" atau "meraih" sesuatu. Istilah kalima-lima ditujukan kepada seseorang yang suka mengambil barang yang bukan miliknya atau mengutil.

Selain bagian tubuh luar, masyarakat Muna juga mengenal metafora yang menggunakan organorgan tubuh bagian dalam. Organ tubuh pertama adalah buku (tulang), penggunaan bagian tubuh ini dapat ditemukan dalam ungkapan kampuro buku atau malu buku. Kampuro buku merupakan gabungan dari morfem ka- [prefiks menyatakan adanya benda diluar frasa] dan frasa puro [ adj. garing] + buku [n. tulang]. Jadi secara harfiah sitilah kampuro buku bermakna benda diluar frasa yang memiliki tulang garing. Sedangkan secara kultural istilah ini merujuk pada hewan yang masih muda. Dasar pemetaforaan dari istilah ini adalah karena kekuatan tulang dari binatang yang berusia muda lebih kecil dibandingkan dengan ketika sudah berusia dewasa. Sehingga jika menyantap hidangan berbahan baku hewan dengan usia yang masih muda masyarakat Muna biasanya akan menggerus tulang dari hewan tersebut untuk menambah kenikmatan dari masakan yang disajikan. Istilah kedua yang berkaitan dengan bagian dalam tubuh berupa tulang adalah malu buku.

Tulang merupakan bagian dalam tubuh yang memiliki fungsi sebagai penopang sehingga tubuh dapat berdiri dengan tegak. Istilah malu buku yang secara harfiah berarti "tulang lembut", secara kultural dimaksudkan pada kondisi dimana seseorang dalam keadaan sangat lelah atau lemas sehingga tidak dapat berdiri. Dasar pemetaforaan istilah ini adalah keadaan tubuh yang seperti memiliki tulang namun tidak lagi keras melainkan berubah menjadi lunak sehingga tidak lagi mampu untuk menopang tubuh. Dari data-data tersebut dapat ditarik kesimpulan bahwa dalam menggunkan istilah organ tubuh buku masyarakat Muna selalu mengaitkannya dengan "kekuatan fisik". Jika untuk merujuk pada keadaan seseorang yang lemah digunakan istilah malu buku maka untuk merujuk pada seseorang yang memiliki kekuatan fisik masyarakat Muna akan menggunakan istilah ghosa buku yang berasal dari kata ghosa [adj. keras] + buku [n. tulang]. Contoh penggunaan istilah ini dapat kita lihat melalui kalimat mie awatu nefodoli kontu bhalano rampano noghosa bukuno (orang itu dapat membalikkan batu karena badannya kuat).

Organ tubuh bagian dalam lainnya yang digunakan dalam pemetaforaan adalah lalo atau hati. Ungkapan metafora dengan menggunkana kata lalo merupakan ungkapan metafora anggota tubuh terbanyak yang dapat ditemukan. Dalam bahasa Muna terdapat beberapa beberapa istilah metafora menggunakan hati yang memiliki kesamaan makna misalnya bhala lalo (besar hati), bhawo lalo (tinggi hati), aporo lalo (gelap hati) dan bhie lalo (berat hati). Istilah metafora dengan menggunakan kata hati yang pemaknaannya hanya dipahami oleh masyarakat Muna misalnya bughou lalo, duko lalo, dan ghughi lalo. Ungkapan-ungkapan menggunakan kata hati ini selalu menyangkut dengan 
emosi manusia yang tidak terlihat. Emosi ini kemudian ingin lebih dikongkretkan dengan jalan pemetaforaan.

Ungkapan bughou lalo secara harfiah berarti hati yang baru namun secara kultural dalam bahasa Muna diartikan sebagai bersenang hati. Hal ini didasari pada pemikiran dan harapan masyarakat Muna bahwa hal baru yang menggantikan sesuatu yang lama akan mendatangkan kebahagian. Hal ini dibuktikan dengan penggunaan ungkapan ini ketika seseorang baru saja mendapatkan sesuatu. Sedangkan ungkapan duko lalo yang secara harfiah berarti hati yang tumpul secara kultural digunakan untuk merujuk pada sifat malas. Sama seperti benda tajam yang tidak dapat digunkan karena tumpul, manusia pun tidak akan bekerja jika rasa malas ada dalam hatinya. Jika benda tajam akan dihancurkan oleh karatnya sediri karena tidak pernah bekerja demikian pula dengan manusia yang akan di hancurkan oleh rasa malasnya jika dia tidak segera menyingkirkan rasa malas itu. Sedangkan yang terakhir ungkapan ghughi lalo secara harfiah berarti hati yang kasar. Kosa kata ghugi biasanya digunakan untuk menggambarkan kondisi dari suatu permukaan benda yang berdebu sehingga tidak nyaman untuk disentuh. Secara kultural ungkapan ini ditujukan untuk orang yang susah untuk menerima ataua mendengar perkataan orang lain. Hal ini didasari pada keyakinan bahwa seseorang yang tidak mau menerima saran orang lain berarti memiliki hati yang kurang bersih sehingga situasi ini disamakan dengan permukaan benda yang berdebu atau kurang bersih.

Selain tulang dan hati, ditemukan pula metafora yang menggunakan anggota tubuh bagian dalam yang lain yaitu darah pada ungkapan late rea. Ungkapan ini merujuk pada keadaan seorang wanita yang tengah mengandung. Secara harfiah arti dari ungkapan ini adalah darah yang tertinggal. Pemetaforaan ini didasari pada pemahaman masyarakat terhadap tahap awal terbentuknya janin. Walaupun tidak mengetahui secara pasti bahwa darah yang menggumpal akan menempel di dinding rahim, namun masyarakat mengetahui bahwa adalah darah yang menggumpal merupakan proses awal terbentuknya janin yang akan menjadi manusia dalam rahim ibunya.

\section{KESIMPULAN}

Sebagai salah satu masyarakat pengguna bahasa masyarakat Muna memiliki pandangan dan pemahaman tersendiri terhadap metafora-metafora yang mereka gunakan. Sebagian dari pemetaforaan tersebut memiliki kesamaan dengan bahasa Indonesia atau rumpun bahasa Austronesia lainnya akan tetapi banyak pula istilah-istilah yang hanya dipahami oleh masyarakat yang hidup dengan budaya dan menuturkan bahasa Muna.

Setidaknya terdapat empat dasar pemetaforaan anggota tubuh bagi masyarakat Muna yaitu berdasarkan letak, fungsi, sifat dan bentuk dari anggota tubuh. Masyarakat Muna menilai bahwa letak dari anggota-anggota tubuh tidak hanya disusun secara acak melainkan memiliki maknanya masing masing. Anggota tubuh merupakan sesuatu yang sangat dekat dengan diri manusia sehingga dalam bahasa Muna sendiri pemetaforaan dengan istilah ini merupakan pemetaforaan terbanyak dibandingkan dengan tiga jenis metafora lainnya yang tidak didapatkan dalam rumpunan bahasa selain Austronesia. Pemetaforaan ini dimaksudkan untuk mengkonkretkan konsep-konsep lain yang lebih abstrak. Selain membuktikan bahwa terbatasnya kosa kata tidak membuat kreatifitas pengguna bahasa menjadi sempit hal ini juga membuktikan bahwa masyarakat menggunkan sesuatu yang sangat dengan dengan lingkungan sosial dan budaya dalam mengkonstruksi sebuah metafora.

\section{DAFTAR PUSTAKA}

Apriatin, Wa Ode. 2015. "Metafora Dalam Khabanti Pada Masyarakat Muna di Kabupaten Muna." JURNAL HUMANIKA 3 (16). http://ojs.uho.ac.id/index.php/HUMANIKA/article/view/755.

Blust, Robert. 2013. The Austronesian Languages. Canberra: Pacific Linguistics, Research School of Pacific and Asian Studies, The Australian National University.

Chairani, Eva. 2017. "Kajian Kognitif Semantik Penggunaan Anggota Tubuh Dalam Peribahasa Indonesia." Medan: Universitas Sumatra Utara. doi:10.31227/osf.io/puvdk.

Couvreur, J. 2001. Sejarah dan kebudayaan Kerajaan Muna. Kupang: Artha Wacana Press.

Haula, Baiq. 2020. "Metafora Konseptual dalam Judul Berita Kontan.co.id: Kajian Linguistik Kognitif." SUAR BETANG 15 (1): 15-24. doi:10.26499/surbet.v15i1.118. 
Lyra, Hera Meganova. 2016. "Piranti Lingual Metafora Orientasional Bagian Tubuh Dalam Bahasa Sunda." Riksa Bahasa: Jurnal Bahasa, Sastra, dan Pembelajarannya 2 (1). doi:10.1750g/rb.v2i1.8772.

Nirmala, Deli. 2012. "Korespondensi Konseptual Antara Ranah Sumber Dan Ranah Target Dalam Ungkapan Metaforis Di Surat Pembaca Harian Suara Merdeka." HUMANIKA 15 (9). Faculty of Humanities, Diponegoro University. doi:10.14710/humanika.15.9.

Rachmawati, Dita. 2019. "Metafora Tangan Dalam Idiom Bahasa Jepang Berdasarkan Teori Metafora Konseptual." LITE: Jurnal Bahasa, Sastra, Dan Budaya 15 (1): 31-47. doi:10.33633/lite.v15i1.2393.

Subhan, Regi Fajar, Tajudin Nur, dan Tubagus Chaeru Nugraha. 2019. "Konseptualisasi Sifat dan Perbuatan Dalam Metafora Berunsur Tubuh 'Tangan' Pada Al-Qur'an." Kandai 15 (1): 61-74. doi:10.26499/jk.v15i1.1287.

Wijana, I Dewa Putu. 2020. "Metaphors of Turtle Dove Physical Characteristics in Javanese Community: A Preliminary Study." Dalam The Conference of the Global Council for Anthropological Linguistics in Asia, 48-52. Malaysia: The Global Council For Anthropological Linguistics. https://glocal.soas.ac.uk/cala2020-proceedings/.

Yusuf, Muri. 2016. Metode Penelitian Kuantitatif, Kualitatif \& Penelitian Gabungan. Jakarta: Prenada Media. 